\title{
Keefektifan Model Kooperatif Tipe Numbered Heads Together Berbantu Media Roda Pintar terhadap Hasil Belajar IPA Siswa
}

\author{
Novi Handayani ${ }^{*}{ }^{*}$, Arfilia Wijayanti ${ }^{2}$, Ikha Listyarini ${ }^{3}$ \\ 1,2,3 Jurusan Pendidikan Guru Sekolah Dasar (PGSD), Universitas PGRI Semarang, Indonesia.
}

\author{
A R T I C L E I N F O \\ Article history: \\ Received 20 August 2018 \\ Received in revised form \\ 9 September 2018 \\ Accepted 15 October 2018 \\ Available online 25 \\ November 2018 \\ Kata Kunci: \\ IPA, Hasil Belajar, Media \\ roda pintar, Model \\ kooperatif, model \\ Numbered Heads Together. \\ Keywords: \\ Science, Learning Outcomes, \\ Smart Wheel Media \\ Cooperative Model, \\ Numbered Heads Together
}

\begin{abstract}
A B S T R A K
Berdasarkan hasil observasi di SD Negeri 03 Gubug menunjukkan bahwa dalam proses pembelajaran yang masih menggunakan model ceramah dan tidak ada pengunaan media pembelajaran yang menyebabkan siswa menjadi pasif dan kurang aktif dalam mengikuti pelajaran. Permasalahan dalam penelitian ini adalah apakah dengan penggunaan model kooperatif tipe Numbered Heads Together berbantu media roda pintar efektif terhadap hasil belajar siswa pada pelajaran IPA siswa kelas III di SD Negeri 03 Gubug. Tujuan yang hendak dicapai dalam penelitian ini adalah untuk mengetahui hasil belajar model kooperatif tipe Numbered Heads Together berbantu media roda pintar terhadap hasil belajar IPA siswa kelas III SD Negeri 03 Gubug. Jenis penelitian ini merupakan penelitian kuantitatif. Hasil penelitian menunjukkan bahwa model kooperatif tipe Numbered Heads Together berbantu media roda pintar efektif terhadap hasil belajar siswa pada pembelajaran IPA di SD Negeri 03 Gubug. Terlihat presentase ketuntasan belajar naik dari $10 \%$ menjadi $80 \%$.
\end{abstract}

\section{A B S T R A C T}

Based on the results of observations at the Public Elementary School 03 Gubug, it was shown that in the learning process still using the lecture model and no use of instructional media that caused students to be passive and less active in attending lessons. The problem in this study is whether the use of the Numbered Heads Together cooperative model is assisted by the smart wheel media effective on student learning outcomes in third grade science students in Public Elementary School 03 Gubug. The aim to be achieved in this study was to find out the learning outcomes of the Numbered Heads Together cooperative model assisted by smart wheel media to the science learning outcomes of third grade students of SD Negeri 03 Gubug. This type of research is quantitative research. The results showed that the Numbered Heads Together cooperative model was assisted by smart wheel media effective on student learning outcomes in science learning in Public Elementary School 03 Gubug. It appears that the percentage of learning completeness rose from $10 \%$ to $80 \%$. 



\section{Pendahuluan}

Pendidikan merupakan faktor yang sangat penting di setiap bangsa karena pendidikan adalah inti sari dari setiap komponen kehidupan manusia karena memiliki peran dan tanggung jawab untuk mengembangkan bakat dan kemampuan secara optimal. Pendidikanpun membuat siswa dari yang tidak tahu menjadi tahu untuk mengembangkan kemampuan yang dikembangkannnya serta berguna bagi diri sendiri dan orang lain. Proses hasil belajar dan hasil belajar para siswa bukan saja ditentukan oleh sekolah, pola ,stuktur , dan isi kurikulumnya, akan tetapi sebagian besar ditentukan oleh kompetensi guru yang mengajar dan membimbing siswa.

Dalam Undang-Undang Republik Indonesia Nomor 20 Tahun 2003 tentang Sistem Pendidikan Nasional pada pasal 1 dapat diketahui bahwa "Pendidikan adalah usaha sadar dan terencana untuk mewujudkan suasana belajar dan proses pembelajaran agar peserta didik secara aktif mengembangkan potensi dirinya untuk memiliki kekuatan spiritual keagamaan, pengendalian diri, kepribadian, kecerdasan, akhlak mulia, serta keterampilan yang diperlukan dirinya, masyarakat, bangsa dan negara". Pembelajaran yang dilaksanakan di sekolah tidak dapat terlepas dari peran seorang guru dalam menciptakan suasana belajar yang bermakna, kreatif, dinamis dan menyenangkan. Pembelajaran yang bermakna dan menyenangkan akan menumbuhkan minat belajar siswa.

Jika dalam suatu proses pembelajaran guru hanya berperan sebagai sumber informasi tanpa diiringi suasana belajar yang menyenangkan maka siswa cenderung akan mudah bosan dan pasif dalam proses pembelajaran. Maka untuk menciptakan suasana pembelajaran yang bermakna, kreatif, dinamis dan menyenangkan bagi siswa guru haruslah menciptakan suatu variasi pembelajaran agar siswa tidak mudah bosan dan pasif dalam proses pembelajaran. Variasi pembelajaran yang dapat dilakukan oleh guru diantaranya adalah dengan menggunakan suatu model atau metode pembelajaran yang berbantu dengan media sederhana yang dapat dibuat sendiri oleh guru, sehingga dalam proses pembelajaran akan mampu menumbuhkan serta meningkatkan semangat dan minat.

Penggunaan model dan media dalam pembelajaran diharapkan dapat meningkatkan prestasi belajar siswa sesuai dengan tujuan pembelajaran yang hendak dicapai. Seperti pada mata pelajaran Ilmu Pengetahuan Alam (IPA), dimana dalam proses pembelajaran siswa dituntut untuk dapat menanamkan kebiasaan berpikir dan berperilaku ilmiah yang kritis, kreatif dan mandiri (Permendiknas No. 22 tahun 2006 tentang Standar Isi).

Mata pelajaran Ilmu Pengetahuan Alam (IPA) adalah salah satu mata pelajaran yang harus dikuasai oleh siswa Sekolah Dasar. Keterampilan dan pengetahuan itu diperluas dari konteks yang terbatas (sedikit demi sedikit). Penting bagi siswa tahu untuk apa dia belajar dan bagaimana ia menggunakan pengetahuan dan keterampilan itu. Sesuai dengan kenyataan bahwa aktivitas dalam IPA selalu berhubungan dengan percobaan-percobaan yang membutuhkan keterampilan dan kerajinan. Dengan demikian, IPA bukan hanya kumpulan pengetahuan tentang benda tak hidup dan makhluk hidup, tetapi menyangkut cara kerja, cara berpikir, dan cara memecahkan masalah.

Menurut Samatowa, (2010: 3) mengemukakan bahawa "IPA adalah suatu cara atau metode untuk mengamati alam, bahwa cara IPA mengamati dunia ini bersifat analisis, lengkap, cermat, serta menghubungkannya antara suatu fenomena dengan fenomena lain, sehingga keseluruhannya membentuk suatu perspektif yang baru tentang objek yang diamatinya". Berdasarkan pendapat tersebut, dapat dikatakan bahwa IPA membahas tentang fenomena-fenomena alam yang dikaji secara sistematis serta berdasarkan pada hasil percobaan dan pengamatan yang dilakukan oleh manusia. Menurut Samatowa (2010: 5) yang mengatakan bahwa "pengalaman langsung yang memegang peran penting sebagai pendorong lajunya perkembangan kognitif anak". Sehingga dengan demikian dalam Pembelajaran Ilmu Pengetahuan Alam yang berlangsung haruslah melihat perkembangan kognitif pada siswa agar tujuan pembelajaran IPA yang hendak dicapai dapat tercapai.

Berdasarkan hasil observasi peneliti dengan guru kelas III di SD Negeri 03 Gubug, dapat disimpulkan bahwa hasil belajar IPA siswa rendah. Banyak nilai dibawah Kriteria Ketuntasan Minimum (KKM) sekitar 60\%. Padahal nilai Kriteria Ketuntasan Minimum (KKM) yang ditetapkan sekolah yaitu 63. Dari hasil observasi, dijumpai 12, dari 20 siswa yang nilainya dapat mencapai KKM. Hal itu disebabkan karena ditemukan adanya kendala yang dihadapi oleh guru dan siswa SD Negeri 03 Gubug ketika melaksanakan pembelajaran IPA. Kendala yang dihadapi dalam kegiatan pembelajaran dikelas yaitu siswa belum bisa berkonsentrasi penuh saat mengikuti pelajaran dikarenakan guru belum bervariasi dalam menggunakan model.

Guru harus mampu memilih dan Menentukan metode/model pembelajaran serta alat-alat pelajaran yang tepat sehingga proses pembelajaran tersebut dapat mendorong tercapainya hasil belajar yang optimal. Model pembelajaran menurut Suprijono (2012: 46) dapat didefinisikan sebagai kerangka konseptual yang melukiskan prosedur sistematika dalam mengorganisasikan pengalaman belajar untuk 
mencapai tujuan belajar. Dalam hal ini, model pembelajaran tidak hanya digunakan untuk mencapai hasil belajar yang memuaskan saja akan tetapi siswa juga terbiasa menyelesaikan suatu masalah secara mandiri.

Dalam pemilihan suatu model seorang guru harus memperhatikan dan mempertimbangkan tujuan pembelajaran yang akan dicapai. Rosdiani (2012: 3) "model merupakan representasi dari suatu abstraksi realistis, model merupakan gambaran tentang suatu, bagaimana hendaknya dan atau bagaimana adanya sesuatu itu". Dengan begitu model dapat dikatakan sebagai gambaran mengenai suatu hal yang dapat memperjelas berbagai hal yang berkaitannya diantara unsur-unsur yang ada. Bruce Joice dan Marsha Weil (dalam Rosdiani, 2012: 7) "model mengajar adalah suatu rencana atau pola yang digunakan dalam menyusun kurikulum, mengatur materi pembelajaran dan membuat petunjuk kepada pengajar di kelas atau di lapangan dalam seting pengajaran atau seting lainnya". Berdasarkan teori tersebut dapat diketahui bahwa model mengajar lebih menekankan pada penyusunan dan pembuatan petunjuk pembelajaran di kelas. Untuk dapat mencapai tujuan tersebut maka model yang dipilih haruslah disesuaikan dengan kebutuhan dan keadaan siswa. Sehingga diharapakan pembelajaran yang dilaksanakan dapat mengaktifkan siswa dan dapat mencapai tujuan pembelajaran dengan maksimal.

Model pembelajaran yang dapat dijadikan solusi untuk mengatasi Masalah tersebut adalah model pembelajaran Numbered Heads Together. Iru (2012: 59) menyatakan bahwa "Model Numbered Heads Together merupakan salah satu tipe pembelajaran yang menekankan pada struktur-struktur khusus untuk memengaruhi pola-pola interaksi siswa dan memiliki tujuan untuk meningkatkan penguasaan tingkat akademik" Penggunaan model ini juga berbantu media roda pintar. Menurut pendapat Al-Tabany (2014: 131) mengemukakan bahwa "Numbered Heads Together" (NHT) atau penomoran berpikir bersama merupakan jenis pembelajaran kooperatif yang dirancang untuk memenuhi pola interaksi siswa dan sebagai alternative terhadap struktur kelas tradisional.

Langkah-langkah pembelajaran model Numbered Heads Together menurut Al-Tabany (2014: 130) yaitu: (1) Penomoran, Dalam fase ini guru membagi siswa ke dalam kelompok 3-5 orang. Dan kepada setiap anggota kelompok diberi nomor 1 sampai 5, (2) Mengajukan pertanyaan, Guru mengajukan suatu pertanyaan kepada siswa. Pertanyaan dapat bervariasi. Pertanyaan dapat sangat spesifik dan dalam bentuk kalimat tanya, (3) Berpikir bersama, Siswa menyatukan pendapatnya terhadap jawaban pertanyaan itu, dan meyakinkan setiap anggota timnya mengetahui jawaban tim, (4) Menjawab, Guru memanggil suatu nomor tertentu, kemudian siswa yang nomornya sesuai mengacungkan tangannya dan mencoba untuk menjawab pertanyaan untuk seluruh kelas. Kelebihan Numbered Heads Together Melatih siswa untuk dapat bekerja sama dan menghargai pendapat orang lain, melatih siswa untuk bisa menjadi tutor sebaya, memupuk rasa kebersamaan, membuat siswa menjadi terbiasa dengan perbedaan (Hamdayama, 2015: 175). Kekurangan Numbered Heads Together Siswa yang sudah terbiasa dengan cara konvensional akan sedikit kewalahan, guru harus bisa memfasilitasi siswa, tidak semua mendapat giliran (Hamdayama, 2015: 175).

Murtita dkk (2014) menyatakan menggunakan model "Numbered Heads Together" dapat meningkatkan hasil belajar matematika siswa kelas V SD Alas Angker yaitu 16,37 yang berada pada kategori sangat baik. Berdasarkan teori tersebut, dapat diketahui bahwa keaktifan siswa di kelas dapat dibagun dengan menggunakan metode Numbered Heads Together dengan memberikan kesempatan kepada setiap siswa untuk berperan menajadi guru untuk teman-temannya. Penelitian Rika Fima Yenni (2016) menyatakan hasil belajar matematika siswa yang menggunakan metode NHT lebih baik dari pada hasil belajar matematika siswa yang menggunakan pembelajaran konvensional. Nursyamsi SY (2016) menyatakan dari perbandingan rerata terkoreksi diketahui bahwa strategi pembelajaran NHT memberikan pengaruh lebih besar, yaitu sebesar 21,56\%, dibandingkan pengaruh yang disebabkan oleh pembelajaran konvensional..

Berdasarkan uraian diatas, dapat disimpulkan bahwa setiap model pembelajaran memiliki kelebihan dan kekurangan tersendiri. Untuk mengatasi masalah tersebut peneliti mengatasi permasalahan tersebut dengan penggunaan media pembelajaran. Media yang peneliiti gunakan adalah media roda pintar. Media adalah segala sesuatu yang dijadikan sebagai sarana untuk mempermudah dalam penyampaian pesan. Menurut Kustandi dan Sutjipto (2013: 7) mengemukakan "Media adalah wadah dari pesan yang oleh sumbernya ingin diteruskan kepada sarana atau penerima pesan tersebut"

Menurut Arsyad (2013:4) mengemukakan bahwa "media sebagai semua bentuk perantara yang digunakan oleh manusia untu menyampaikan atau menyebarkan ide, gagasan, atau pendapat sehingga ide, gagasan atau pendapat yang dikemukakan itu sampai kepada penerima yang dituju". Peran media dalam pembelajaran perlu diperhatikan oleh seorang guru, karena dengan penggunaan media dalam proses belajar mengajaran mampu memperjelas pesan yang disampaikan oleh guru, menumbuhkan semangat belajar bagi siswa, pembelajaran akan menjadi lebih menarik dan memungkinkan siswa untuk belajar mandiri sesuai dengan kemampuan dan ketrampilan yang dimilikinya. Oleh karena itu, media roda pintar 
dirancang untuk membantu guru dalam menyampaikan materi kepada siswa secara mudah dan tepat. Media roda pintar adalah sebuah alat yang memfasilitasi siswa dalam belajar di dalam kelas, yang mana didalamnya terdapat kegiatan bermain agar selama proses pembelajaran siswa tidak merasa bosan dan jenuh.

Melalui media roda pintar akan membantu meningkatkan minat belajar siswa karena roda pintar ini dikemas dalam bentuk yang sederhana yaitu berbentuk bundar yang dibagi menjadi beberapa bagian dan diberikan nomor di setiap bagiannya. Di setiap nomornya juga telah berisikan pertanyaan-pertanyaan yang akan dijawab oleh siswa. Penggunaan model pembelajaran Numbered Heads Together berbantu media roda pintar ini diharapkan akan memberikan variasi pembelajaran. Sehingga siswa tidak akan merasa bosan dan pasif dalam pembelajaran serta meningkatkan hasil belajar siswa kelas III SD Negeri 03 Gubug menggunakan model pembelajaran Numbered Heads Together berbantu media roda pintar.

Dari permasalahan tersebut penting dilakukan penelitian tentang "Keefektifan Model kooperatif tipe Numbered Heads Together Berbantu Media Roda Pintar Terhadap Hasil Belajar Siswa Kelas III SD Negeri 03 Gubug".

\section{Metode}

Penelitian ini merupakan penelitian kuantitatif dengan pre eksperimental One-Group PretetPosttest Design yang bertujuan untuk mengetahi pengaruh model pembelajaran Numbered Heads Together. Dalam penelitian ini peneliti menggunakan satu kelas yaitu kelas III dengan jumlah siswa sebanyak 20 anak. Sampel pada penelitian siswa kelas III SD Negeri 03 Gubug, yang berjumlah 20 siswa akan dijadikan sebagai sampel yang berjumlah 20 siswa.

Teknik sampling adalah merupakan teknik pengambilan sampel (Sugiyono. 2015: 118). Teknik sampling yang digunakan dalam penelitian ini adalah sampling jenuh. Sampling jenuh adalah teknik penentuan sampel bila semua anggota populasi digunakan sebagai sampel (Sugiyono. 2015: 124).

Teknik pengumpulan data pada penelitian ini adalah observasi, Sutrisno hadi (dalam Sugiyono, 2015: 203) mengemukakan bahwa "observasi merupakan suatu proses yang kompleks, suatu proses yang tersusun dari berbagai proses biologis dan psikologis". Berdasarkan pendapat tersebut, observasi merupakan teknik pengumpulan data yang dilakukan dengan cara mengamati suatu proses yang kompleks dengan menggunakan seluruh alat indra.

Observasi dalam penelitian ini digunakan untuk mengetahui sikap siswa selama pembelajaran dengan menggunakan model pembelajaran Numbered Heads Together. Observasi yang digunakan dalam penelitian ini berupa observasi yang sudah dirancang sesuai dengan tujuan penelitian yaitu meningkatkan hasil belajar siswa kelas III SD Negeri 03 gubug, serta mengetahui tingat motivasi siswa.

Tes adalah serentetan pertanyaan atau latihan atau alat lain yang digunakan untuk mengukur keterampilan, pengetahuan, intelegensi, kemampuan, atau bakat yang dimiliki oleh individu atau kelompok (Arikunto, 2006: 150). tes yang digunakan dalam penelitian ini adalah untuk mengetahui keterampilan berpikir kritis siswa sebelum diberikan dan setelah diberi perlakuan dengan menggunakan intrumen berupa tes yaitu pretest dan postest. Sub indikator yang digunakan dalam penelitian ini mengacu pada hasil belajar siswa. Soal tes berupa pilihan ganda yang berjumlah 20 soal.

Instrument penelitian dalam penelitian ini menggunakan uji validitas dimana menggunakan rumus.

$$
r_{x y}=\frac{N \sum X Y-\left(\sum X\right)\left(\sum Y\right)}{\sqrt{\left.\left\{N \sum X^{2}-\left(\sum X\right)^{2}\right\} N \sum Y^{2}-\left(\sum Y\right)^{2}\right\}}}
$$

$$
\begin{aligned}
& \text { Keterangan: } \\
& \mathrm{X}=\text { skor butir soal yang akan dicari validitasnya } \\
& \mathrm{Y}=\text { skor total peserta tes } \\
& \mathrm{N}=\text { jumlah peserta didik } \\
& r_{x y}=\text { koefisien korelasi antara variabel } \\
& \mathrm{x} \text { dan } y \text { (indeks validitas) }
\end{aligned}
$$

Dalam penelitian ini peneliti menggunakan uji korelasi product moment untuk mengukur apakah ada hubungan antara motivasi belajar siswa dengan kemampuan berpikir kritis siswa. 


\section{Hasil dan Pembahasan}

Berdasarkan hasil analisis menunjukkan bahwa penerapan model pembelajaran kooperatif tipe NHT (Numbered Head Together) Berbantu Media Roda Pintar dapat meningkatkan hasil belajar IPA siswa. Peningkatan Hasil Belajar siswa dari Dalam penelitian ini dapat diketahui melalui pelaksanaan post test di akhir proses pembelajaran. Sebelum memberikan siswa post test [eneliti terlebih dahulu menyaipkan soal sebanyak 20 butir soal yang valid, sedangkan 10 butir soal yang tidak valid. Hal tersebut dapat dibuktikan melalui Tabel 1 dibawah ini.

Tabel 1. Hasil Pengujian Validitas Instrumen Tes

\begin{tabular}{ll}
\hline \multicolumn{1}{c}{ Nomor Soal } \\
\hline \multicolumn{1}{c}{ Valid } & \multicolumn{1}{c}{ Tidak Valid } \\
\hline $2,3,4,6,8,9,10,15,16,17,18,19,21,22,23,25,31,33$, & $1,5,7,11,12,13,14,20,24,26,27,28,29,30,32,3$ \\
$35,36,37,39$ & $4,38,40$ \\
\hline
\end{tabular}

Arikunto (2012 : 100) mengatakan bahwa "suatu tes dapat dikatakan mempunyai taraf kepercayaan yang tinggi jika tes tersebut dapat memberikan hasil yang tetap". Dalam penelitian ini, semua soal adalah reliabel. Pernyataan tersebut dapat dibuktikan melalui Tabel 2. dibawah ini.

Tabel 2. Hasil Pengujian Reliabilitas Instrumen Tes

\begin{tabular}{ll}
\hline \multicolumn{1}{c}{ Nomor Soal } & Reliabilitas \\
\hline $2,3,4,6,8,9,10,15,16,17,18,19,21,22,23,25,31,33$, & \\
$35,36,37,39$ & Reliabel \\
\hline
\end{tabular}

Daya pembeda soal adalah kriteria yang dimiliki oleh sebuah soal dalam membedakan antara siswa yang memiliki kemampuan yang tinggi dan siswa yang memiliki kemampuan yang rendah.

Tabel 3. Daya Pembeda Soal Instrumen Tes

\begin{tabular}{ll}
\hline \multicolumn{1}{c}{ Nomor Soal } & Daya Pembeda \\
\hline $4,6,9,11,15,17,39$ & Baik \\
$1,2,10,16,18,22,23,25,26,27,28,31,33,34,35,36,37,38$ & Cukup \\
$3,5,7,12,14,19,20,21,24,29,30,32,40$ & Jelek \\
\hline
\end{tabular}

Arikunto (2012 : 222) mengatakan bahwa "Soal yang baik adalah soal yang tidak terlalu mudah atau tidak terlalu sukar. Soal yang terlalu mudah tidak merangsang siswa untuk mempertinggi usaha memecahkannya"

Setelah dilakukan uji coba instrumen, peneliti melakukan penelitian di SD Negeri 03 Gubug. Pada awal penelitian peneliti meminta data hasil ulangan harian mapel IPA yang akan dijadikan sebagai nilai pretest. Pengambilan nilai ulangan harian tersebut bertujuan untuk mengetahui kemampuan awal siswa sebelum mendapatkan perlakuan dengan model Numbered Heads Together berbantu media roda pintar.

Rekapitulasi hasil pretest dan posttest dapat ditujukkan melalui gambar presentase ketuntasan pretest dan posttest dibawah ini.

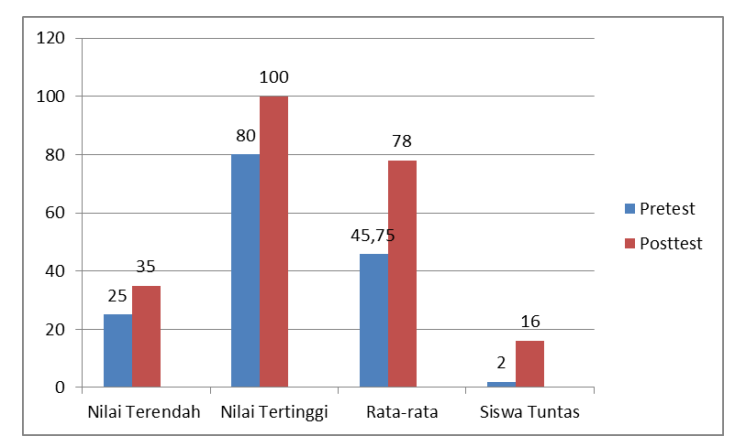

Gambar 1 Diagram Persentase ketuntasan 
Berdasarkan gambar 1 menunjukkan bahwa ada peningkatan antara nilai pretest sebelum diberikan perlakuan dan posttest setelah diberikan perlakuan dengan menggunakan model Numbered Heads Together berbantu media roda pintar pada pembelajaran IPA.

Hasil nilai pada penelitian ini yang dijadikan sebagai data akhir penelitian yaitu nilai posttest. Data yang diperoleh kemudian digunakan uji normalitas dan uji t untuk menguji hipotesis penelitian ada atau tidak ada perbedaan hasil belajar yang signifikan antara pretest dan posttest.

Perhitungan normalitas dalam penelitian ini menggunakan uji Liliefors dengan taraf signifikansi sebesar 5\%. Uji normalitas dilakakukan bertujuan untuk mengetahui apakah sampel berasal dari populasi yang berdistribusi normal. Berdasarkan tabel 6 perhitungan uji normalitas kelas responden diperoleh harga mutlak selisih yang paling besar $\mathrm{L}_{0}=0,142$ dengan $\mathrm{n}=20$ dan taraf nyata $\alpha=5 \%$ dari daftar nilai kritis $\mathrm{L}$ didapat $\mathrm{L}_{\text {tabel }}=0,190$ karena $\mathrm{L}_{0}<\mathrm{L}_{\text {tabel }}$ yaitu $0,142<0,190$ maka $\mathrm{H}_{0}$ diterima. Sehingga dapat disimpulkan bahwa data posttest siswa berasal dari populasi yang berdistribusi normal. Hasil posttes menunjukkan bahwa ada perbedaan hasil belajar antara sebelum dengan sesudah perlakuan. Berdasarkan data pada tabel tersebut, kemudian disajikan dalam bentuk diagram ketuntasan preetest dan posttest siswa kelas III SD Negeri 03 Gubug sebagai berikut:

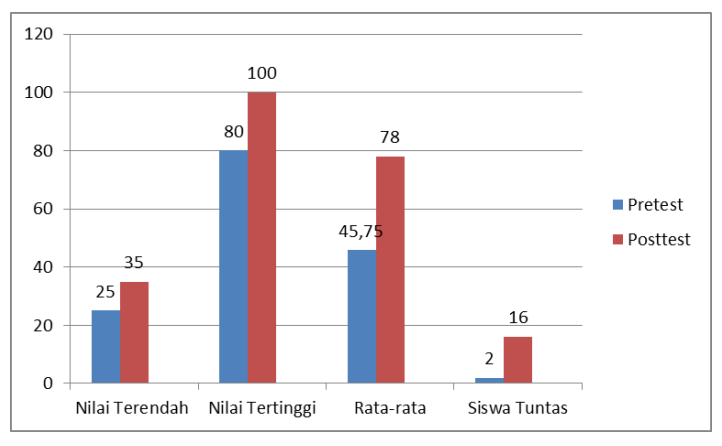

Gambar 2 Diagram Ketuntasan Nilai Preetest dan Nilai Posttest

Berdasarkan perbedaan nillai preetest dan posttest pada gambar 2 merupakan hasil dari kegiatan belajar yang telah dilakukan. Jika siswa mampu mengikuti kegiatan belajar mengajar dengan baik maka tidak akan ada kesulitan dalam mengerjakan soal. Hal tersebut juga diiringi dengan motivasi dari orang tua yang senantiasa memberikan dukungan kepada siswa agar giat belajar dan berkonsentrasi dalam kegiatan belajar mengajar dengan baik.

Terjadinya peningkatan hasil belajar siswa kelas III pada mata pelajaran IPA disebabkan keberhasilan dari penggunaan model Pembelajaran NHT. Numbered Head Together (NHT) adalah salah satu pendekatan struktural, untuk melibatkan lebih banyak siswa dalam menelaah materi yang tercakup dalam suatu pembelajaran dan mengecek pemahaman siswa terhadap isi materi pembelajaran tersebut. Melalui kegiatan pembelajaran dengan menerapkan model kooperatif tipe NHT ini, siswa dituntut aktif dalam mengikuti kegiatan pembelajaran seperti: 1) mengamati penjelasan dan demonstrasi dalam materi media tayang dan LKS; 2) bersungguh-sungguh mengerjakan tugas yang diberikan oleh guru; serta 3) mengajukan pertanyaan dan menjawab pertanyaan tentang materi pembelajaran baik kepada guru maupun kepada teman sebaya; dan 4) perhatian dan keantusiasan siswa dalam melaksanakan model kooperatif tipe NHT yaitu dengan mengikuti setiap langkah-langkah kegiatannya. Aktivitas-aktivitas tersebut telah dilaksanakan dengan baik, sehingga persentase aktivitas belajar siswa meningkat.

Dilihat dari hasil belajar IPA siswa yang mengalami kenaikan dari rata-rata 45,75 menjadi $78 \mathrm{Hal}$ tersebut terjadi karena siswa menanggapi positif tentang penerapan pembelajaran kooperatif tipe NHT, karena dengan model pembelajaran tersebut siswa dapat belajar bekerja sama menyelesaikan tugas yang diberikan oleh guru sehingga siswa yang merasa kurang memahami materi dapat bertanya kepada siswa yang lebih mengetahui. Dengan adanya kerjasama antara siswa maka bukan hanya akan terjadi interaksi antar siswa tetapi juga interaksi antar siswa dan guru, hal tersebut akan mendorong motivasi siswa untuk belajar dan meningkatkan hasil belajar siswa. Penelitian ini sejalan dengan penelitian yang dilakukan oleh Herawati (2014) menunjukkan bahwa dengan penerapan model pembelajaran kooperatif tipe NHT (Numbered Head Together) terdapat peningkatan motivasi belajar siswa dan hasil belajar siswa kelas VII C SMP Negeri 1 Semboro kabupaten Jember pada pokok bahasan pengelolaan lingkungan. Hasil penelitian ini sejalan dengan hasil penelitian Nursyamsi (2016) dengan hasil penelitian bahwa strategi pembelajaran memiliki efek pada retensi. Penelitian Suandewi (2017) dan Juliartini (2017) menunjukkan bahwa penerapan model pembelajaran kooperatif tipe Numbered Head Together (NHT) dapat meningkatkan hasil belajar IPA siswa. Penelitian oleh Mutia Agisni Mulyana (2016) Menyatakan bahwa Model kooperatif 
tipe Numbered Heads Together (NHT) dapat meningkatkan hasil belajar siswa pada materi kenampakan alam dan sosial budaya. Siti Nuryanti (2014) juga menyatakan penerapan model pembelajaran kooperatif tipe Numbered Head Together dapat meningkatkan hasil belajar IPA siswa Kelas IV SD Negeri 3 Tondo Palu.

Melihat peningkatan hasil belajar siswa dalam pembelajaran IPA yang menerapkan model NHT Berbantu Media Roda Pintar, dapat diketahui bahwa Model NHT ini sangat memberikan sumbangan positif dalam proses pembelajaran dan hasil belajar siswa yang optimal serta sangat baik digunakan dalam peningkatan kualitas pembelajaran sekolah dasar. Model NHT Berbantu Media Roda Pintar dapat memudahkan siswa melakukan penyesuaian sosial, mengembangkan kegembiraan belajar yang sejati, memungkinkan siswa saling belajar mengenai sikap, keterampilan, informasi, perilaku, sosial dan pandangan. Dari uraian di atas, secara umum telah mampu menjawab rumusan masalah. Penelitian ini dapat dikatakan berhasil, karena semua kriteria yang ditetapkan telah terpenuhi. Jadi, dapat dinyatakan bahwa penerapan model pembelajaran Kooperatif tipe Numbered Head Together (NHT) Berbantu Media Roda Pintar dapat meningkatkan hasil belajar Siswa Kelas III SD Negeri 03 Gubug".

\section{Simpulan dan Saran}

Berdasarkan hasil penelitian dan pembahasan dalam penelitian ini dapat disimpulkan bahwa model Numbered Heads Together berbantu media roda pintar efektif terhadap hasil belajar IPA siswa kelas III SD N 03 Gubug. Hal ini dibuktikan dengan analisis uji t dimana thitung = 5,9520 > ttabel =1,725 dengan rata-rata nilai pada kelas III adalah 78 dan persentase ketuntasan belajar mencapai 80\%. Yang semula pada presentase ketuntasan pretest hanya $10 \%$ dengan nilai rata-rata 45,75 , setelah dilakukan perlakuan menggunakan model Numbered Heads Together berbantu media roda pintar presentase ketuntasan pada postest meningkat menjadi $80 \%$ dengan rata-rata 78 . Jadi keniakan presentase pada hasil belajar siswa kelas III sebanyak 60.

Berdasarkan hasil penelitian, maka saran yang disampaikan antara lain: (1) Model Numbered Heads Together memberikan pengaruh yang positif pada siswa sehingga guru dapat menerapkannya sebagai salah satu alternatif model pembelajaran yang dapat meningkatkan hasil belajar siswa, (2) Media roda pintar dapat dimanfaatkan sebagai salah satu alternatif media yang membantu siswa dalam memahami materi dan mengembangkan keterampilan serta kreatifitas siswa, (3) Guru hendaknya menggunakan model dan media pembelajaran yang tepat agar tercipta suasana belajar yang aktif, menyenangkan dan efektif sehingga diharapkan hasil belajar siswa dapat meningkat.

\section{Daftar Rujukan}

Al-Tabany, Trianto Ibnu Badar. 2014. Mendisain Model Pembelajaran Inovatif, Progresif, dan Kontektual. Jakarta: Prenada media Group

Arikunto. 2006. Dasar-dasar Evaluasi Pendidikan. Jakarta: Bumi Aksara.

Arikunto, 2012. Dasar-dasar Evaluasi Pendidikan. Jakarta: Bumi Aksara.

Arsyad, Azhar. 2013. Media Pembelajaran. Jakarta: PT Rajagrafindo Persada.

Hamdayama, Jumanta. 2015. Model dan Metode Pembelajaran Kreatif dan Berkarakter. Bogor: Ghalia Indonesia.

Iru, 2012. Analisis Penerapan Pendekatan, Metode, Strategi, dan Model-model Pembelajaran. Kendari: Multi Residu.

Juliartini, N. M. , N. W. Arini. 2017. Penerapan Model Pembelajaran Nht Untuk Meningkatkan Hasil Belajar Ipa Siswa Kelas III. J o u r n a l o f E d u c a t i o n A c t i o n R e s e a r c h Volume 1 Nomor 3

Kustadi, Cecep dan Sutjipto. 2013. Media Pembelajaran: Manual dan Digital. Bogor: Ghalia Indonesia.

Monawati, M. Yamin. 2016. Upaya Meningkatkan Hasil Belajar Siswa Melalui Lesson Study Pada Penjumlahan Pecahan Di Kelas IV Sdn Lamsayeun. JURNAL PESONA DASAR Universitas Syiah Kuala. Vol. 3 No.4, Oktober. 
Mutia Agisni Mulyana, Nurdinah Hanifah, Asep Kurnia Jayadinata. 2016. Penerapan Model Kooperatif Tipe Numbered Heads Together (NHT) Untuk Meningkatkan Hasil Belajar Siswa Pada Materi Kenampakan Alam Dan Sosial Budaya. Jurnal Pena Ilmiah UPI. Vol 1 No 1.

Nursyamsi SY, Aloysius Duran Corebima, Herawati Susilo. 2016. Pengaruh Strategi Pembelajaran Numbered Heads Together (NHT) terhadap Hasil Belajar Siswa SMA Negeri 1 Muara Badak. Jurnal Pendidikan: Teori, Penelitian, dan Pengembangan. Vol 1 No 10 Edisi Oktober.

Nursyamsi SY, Aloysius Duran Corebima, Herawati Susilo. 2016. Pengaruh Strategi Pembelajaran Numbered Heads Together (NHT) terhadap Hasil Belajar Siswa SMA Negeri 1 Muara Badak. Jurnal Pendidikan: Teori, Penelitian, dan Pengembangan. Vol 1 No 10 Edisi Oktober.

Pukjiwati. 2017. Upaya Meningkatkan Aktivitas Hasil Belajar Siswa Pada Materi Pecahan Dengan Pendekatan Contextual Teaching and Learning Kelas IV SDN Sumur 03. JURNAL REFLEKSI EDUKATIKA Universitas Muria Kudus. Volume 7 (2).

Rika Fima Yenni. 2016. Penggunaan Metode Numbered Head Together (NHT) Dalam Pembelajaran Matematika. Jurnal Penelitian dan Pembelajaran Matematika. Jurnal Penelitian dan Pembelajaran Matematika. Vol 9 No 2.

Rusdiani, Dini. 2012. Model pembelajaran langsung. Yogyakarta: Pustaka Pelajar.

Samatowa, Usman. 2010. Pembelajaran IPA di Sekolah Dasar. Jakarta: Indeks.

Siti Nuryanti. 2014. Penerapan Model Pembelajaran Kooperatif Tipe Numbered Head Together (Nht) Untuk Meningkatkan Hasil Belajar Siswa Pada Mata Pelajaran Ipa Kelas IV Sd Negeri 3 Tondo. Jurnal Diknas. Volume 2 No 2.

Suandewi, Ni Km. I Made.Citra Wibawa. (2017). Penerapan Model Pembelajaran Numbered Head Together Meningkatkan Hasil Belajar IPA siswa kelas IV SD No. 3 Kapal. Jurnal Ilmiah Sekolah Dasar. Vol.1 (1) pp 59-66

Sugiyono. 2015. Metode Penelitian Pendidikan. Bandung: Alfabeta.

Widodo, Lusi Widayanti. 2013. Peningkatan Aktivitas Belajar Dan Hasil Belajar Siswa Dengan Metode Problem Based Learning Pada Siswa Kelas Viia Mts Negeri Donomulyo Kulon Progo. Jurnal Fisika Indonesia No: 49, Vol XVII, Edisi April. 